\title{
VALIDACIJA TESTA ZRELOSTI ZA ŠKOLU
}

\section{Zdenka Novović', Snežana Tovilović, Veljko Jovanović i Mikloš Biro Odsek za psihologiju, Univerzitet u Novom Sadu}

Cilj ovog istraživanja je provera psihometrijskih karakteristika Testa zrelosti za školu. Uzorak je činilo 149 dece, prosečne starosti 81 mesec. Podaci su prikupljeni tokom redovne procene zrelosti za školu u osnovnim školama u Šapcu i Sremskoj Mitrovici. Rezultati su pokazali visoku pouzdanost TZŠ. Poređenjem rezultata na TZŠ $i$ TIP-1 dobijena je korelacija ukupnog skora od 0.66, a u visokoj korelaciji su $i$ subtestovi TIP-1 $i$ TZS̆ koji pretenduju da mere slične konstrukte - iz čega je izveden zaključak o visokoj konkurentnoj validnosti TZŠ. Prediktivna validnost TZŠ je proveravana u odnosu na kriterijum učiteljskih procena kognitivnog funkcionisanja dece nakon prvog polugodišta prvog razreda. Rezultati pokazuju da TZŠ predstavlja instrument sa odličnom prediktivnom validnošću, a da najveću prediktivnu moć pokazuju subtestovi Informisanost i Slaganje kocaka.

Ključne reči: zrelost za školu, testovi inteligencije, Test zrelosti za školu

\footnotetext{
${ }^{1}$ E-mail autora: zdenov@unsff.ns.ac.yu

Članak predstavlja rezultat rada na projektu «Integracija romske dece u školski sistem Srbije», koji je finansijski pomogao Pokrajinski sekretarijat za nauku i tehnološki razvoj AP Vojvodine, a finansijski je podržan i sredstvima Ministarstva za nauku i zaštitu životne sredine Republike Srbije (projekat br. 149008).
} 


\section{Uvod}

Vek nakon čuvenog Binea koji je prihvatio izazov rešavanja praktičnog problema selekcije dece koja mogu da se uključe u školovanje, procenjivanje spremnosti dece za polazak u školu predstavlja aktuelan i važan psihološki zadatak. Nakon sto godina bogatiji smo za mnoga (neretko i gorka) iskustva u vezi sa dometima i ograničenjima testova inteligencije uopšte, suočeni sa lošim primerima njihove zloupotrebe, no i dalje pozvani da odgovaramo na zahteve prakse i da donosimo relevantne odluke o deci i odraslima čije intelektualne sposobnosti ispitujemo. U nastojanju da odgovorimo na pitanje da li su testovi inteligencije (ne)zaobilazni, neminovno ostajemo sa zaključkom da, uprkos nesavršenostima, ne postoje "krunski“ dokazi za njihovo odbacivanje, dok postoje brojni dokazi i razlozi zbog kojih su nam potrebni (Tovilović i Baucal, 2007). Tako i procena kognitivnog funkcionisanja dece i dalje predstavlja jedan od nezaobilaznih zadataka psihologije (Hale, Fiorello, Kavanagh, Holdnach, \& Aloe, 2007). Danas preovladava stav da testovi inteligencije mogu pružiti brojne korisne podatke u ove svrhe, naročito ukoliko se posmatraju u širem kontekstu funkcionisanja deteta i integrišu sa podacima dobijenim iz drugih izvora (Kaufman \& Kaufman, 2001).

Moć i nemoć testova inteligencije (kao i psiholoških testova uopšte) često ne potiče isključivo od njih samih, već od toga ko, kako i kada (u koje svrhe) ih koristi. Podesnost testova i način na koji se služimo njima su posebno osetljiva tema kada je reč o proceni kognitivnih sposobnosti dece, upravo zbog implikacija koje se izvode na osnovu detetovog postignuća na testu. Rezultati testiranja detetovih sposobnosti ne tiču se samo njegove edukativne budućnosti oni oblikuju i odnos roditelja, vršnjaka i različitih institucija prema detetu, a u krajnjoj liniji imaju efekta i na detetovo poimanje sebe i razvoj različitih aspekata ličnosti. Tako jedan isti, čak i (zamišljeni) savršen test za procenu spremnosti za polazak u školu može postati sredstvo pomoću kojeg „stručno“ lice u ulozi pukog administratora testa obavlja selekciju „normalne dece“ za „normalne razrede", sredstvo za neetičnu stratifikaciju dece, ali i veoma svrsishodan instrument koji pomaže izvođenju važnih preporuka u korist ispitivanog deteta. To, naravno, ne znači da se možemo (i smemo) zadovoljiti lošim i manjkavim testom koji smo „savesno“ stavili u ruke dobrim praktičarima.

Koje sve zamke i prepreke krije kreiranje dobrog testa za procenu spremnosti za školu? Generalno gledano, teškoće u procenjivanju karakteristika i sposobnosti dece predškolskog uzrasta prvenstveno je neophodno posmatrati u kontekstu osobenosti njihovog uzrasta i karakterističnog razvoja. U sudaru sa pokretnim i promenljivim razvojem dece na ovom uzrastu, naši instrumenti za 
procenu sposobnosti mogu izgledati poput razuđenih mreža kojima je teško uhvatiti tako varljive i stalno-izmičuće konstrukte. Dalje, jedna od najoštrijih i najprisutnijih kritika, upućivanih na račun ispitivanja predškolske dece generalno, odnosi se na pouzdanost i validnost postojećih instrumenata za procenu sposobnosti dece ovog uzrasta (Ulrey, 1981). Pri tome važi sledeće "pravilo": što je uzrast deteta mlađi, instrument postaje pogrešivija alatka, a kritike usmerene na te alatke bivaju glasnije. Na primer, Bagnato i Neisworth (1994) saopštavaju da je u $43 \%$ slučajeva ranim testovima sposobnosti neuspešno utvrđeno (predviđeno) da li je detetu potrebna neka intervencija ili stimulacija. Rezultat koji jedva da premašuje predikciju tipa "pismo-glava"! Rani testovi inteligencije su kritikovani i zbog svoje neprilagođenosti ograničenim mogućnostima dece da odgovaraju na testovne zadatke (niska responsivnost), naročito u neprirodnom i nepoznatom okruženju koje diktira sama testovna situacija. Ipak, testovi za starije predškolce nemaju tako tragičnu sudbinu, tačnije njihova mogućnost predikcije je znatno veća u odnosu na tzv. infant testove. Delom je to stoga što sadržaj testovnih ajtema nije ograničen samo na perceptualno-motorne zadatke, već postoji mogućnost zahvatanja i kognitivnog domena (Sattler, 1992). Međutim, stabilnost testovnih rezultata i predikcija buduće školske uspešnosti ponajviše su u vezi sa uzrastom na kome se dete ispituje. Zapravo, polje u kojem su se testovi inteligencije pokazali naročito korisnim je predikcija edukativnog postignuća. Korelacije IQ skorova sa školskim uspehom najčešće iznose oko 0,50 (Jensen, 1998; Neisser et al., 1996) i pokazuje se da u predviđanju školskog uspeha, naročito u početnim razredima školovanja, skorovi na testovima inteligencije predstavljaju najbolji prediktor (Nijenhuis et al., 2004). Ovaj podatak ne iznenađuje, jer je konstrukcija instrumenata za procenu inteligencije dece od samih početaka i Bine-Simonove skale 1905. godine bila rukovođena pragmatičnim ciljevima - da postignuće na testu što bolje predviđa efikasnost u školi (Sternberg, Grigorenko, \& Bundy, 2001). Međutim, interpretacija postignuća na testovima inteligencije pre pete godine mora biti veoma okvirna i izvedena sa puno opreza, zato što mnogi indikatori kasnijih teškoća u učenju i ponašanju jednostavno nisu podesni za merenje pre uzrasta od šest godina (Ulrey, 1981; Sattler, 1992).

Instrumentima korišćenim za procenu sposobnosti predškolaca stavljana je na dušu i slaba upotrebna vrednost i to iz više razloga. Prvo, kritikovan je loš manir korišćenja testovnih normi koje nisu izvedene na reprezentativnom uzorku. Na primer, mnoge razvojne skale kreirane u Americi pre dve decenije normatizovane su na belcima srednje klase (Garber \& Slater, 1983). Neuzimanje u obzir uzrasta, pola, etničke pripadnosti, socioekonomskog statusa i područja boravka kao značajnih varijabli za standardizaciju uzorka doprinelo je neinterpretabilnosti testovnih rezultata. Tako kreirani testovi su imali nisku ili 
nejednako dobru prediktivnu vrednost za populacije različitog etničkog porekla, socioekonomskog statusa i sposobnosti. Upotrebna vrednost instumenata slabljena je i nedostatkom pratećih testovnih informacija koji bi bili svedočanstvo njihove korisnosti i pouzdanosti. Takve podatke je potrebno obezbediti validacionim studijama, no one katkad nisu sprovođene ili su bile ograničenog opsega (Flanagan \& Alfonso, 1995).

Poseban problem na kom se očitavaju i sjedinjuju sve zamke isprečene na putu adekvatnog testiranja dece na ovom uzrastu predstavlja situacija ispitivanja deteta koje ne pripada dominantnoj kulturi i čije sposobnosti su razvijane u drugačijim, najčešće otežavajućim okolnostima. U situaciji kada pripadnik manjinske populacije biva procenjivan po standardima koji su atipični za njegovu sociokulturnu zajednicu, on će postići niži učinak i ispoljiti „sindrom kulturnog hendikepa" (Berger, Marković i Mitić, 1995). Testovni ajtemi mogu favorizovati određenu grupu ispitanika kroz sadržaje koji su toj grupi bliski ili, pak, diskriminisati one kojima su nedostupni. Ilustrativni su primeri podbačaja romske dece na pojedinim subtestovima Testa zrelosti za polazak u školu (Novović i sar., 2007) sa kojima su se susretali autori instrumenta tokom njegove konstrukcije - romska deca su bila značajno neuspešnija na zadacima koji su uključivali manipulaciju materijalom koji im je tokom odrastanja bio manje dostupan (kockice, delovi figure) i učestalije su ispoljavala nemogućnost imenovanja pojmova koji nisu deo njihovog prirodnog okruženja i iskustva (helikopter, domine) u odnosu na ne-romsku decu istog uzrasta (Biro, Novović i Tovilović, 2006). Načiniti dobar instrument za procenu zrelosti za školu značilo je eliminisati stavke i materijale koji obezbeđuju bolju početnu poziciju deci iz intelektualno i edukativno povoljnijih i naprednijih sredina. $S$ druge strane, da bi test bio reprezentativan za školske zahteve, tj. prediktivno validan za procenu zrelosti $z a$ školu, on neizbežno uključuje neke sadržaje i materijale koji su diskriminativni prema edukativno depriviranoj deci (Novović i sar., 2007).

Procena intelektualnih sposobnosti, uz procenu indikatora emocionalnog i socijalnog funkcionisanja, predstavlja uobičajeni deo procedure ispitivanja spremnosti deteta za školu. U našoj sredini se za procenu kognitivnog funkcionisanja najčešće koriste Nova beogradska revizija Bine-Simonove skale (Ivić i sar., 1976) i Test za ispitivanje prvaka (TIP-1; Ivić, Milinković, Pešikan i Bukvić, 1995). Iako ovi instrumenti predstavljaju standard u školskoj psihološkoj praksi, imaju i određeni broj nedostataka koji ograničavaju njihovu upotrebnu moć. Pre svega, ovi testovi nisu prošli novi proces standardizacije, pa još uvek barataju zastarelim normama (Simić i Mihajlović, 1998; Tovilović i Baucal, 2007). Pored toga, konstruisani su u vreme kada nije bilo afirmisano inkluziv- 
no obrazovanje i kada nije naglašavano da je jedna od ključnih uloga dobrog testa inteligencije nepristrasna procena intelektualnih sposobnosti dece koja dolaze iz edukativno depriviranih, siromašnih, ili sredina koje neguju drugačije socijalne i kulturološke vrednosti.

Zahtevi savremene psihološke prakse i moderna saznanja o prirodi inteligencije, kreirali su potrebu za konstrukcijom novog testa za procenu kognitivnih sposobnosti dece i zrelosti za školu. Zbog navedenih razloga, kao i pomeranja polaska u prvi razred na 6 godina, konstruisan je Test zrelosti za školu (TZŠ; Novović i sar., 2007).

Test zrelosti za školu je novi instrument namenjen proceni spremnosti dece za školu, koncipiran na temeljima Vekslerovog shvatanja inteligencije (Biro, Novović i Tovilović, 2006). TZŠ-om se procenjuju različiti aspekti kognitivnog funkcionisanja - pamćenje, pažnja, vizuomotorna koordinacija, praktična znanja, socijalna prilagođenost itd.

Osim što služi proceni aktuelne kognitivne efikasnosti, TZŠ je namenjen i praćenju intelektualnog razvoja deteta. Ova karakteristika testa je u skladu sa afirmacijom inkluzivnog obrazovanja, gde praćenje kognitivnog funkcionisanja deteta postaje jedan od prioriteta.

Prilikom konstrukcije Testa zrelosti za školu, forma i sadržaj zadataka su osmišljeni tako da minimizuju uticaj kulturalnih, socijalnih i lingvističkih razlika među ispitivanom decom. TZŠ je napravljen sa ciljem da predstavlja validnu, pouzdanu i nepristrasnu meru kognitivnih sposobnosti, što predstavlja ključni zadatak prilikom procene dece koja dolaze iz drugačijih sociokulturnih sredina.

Prethodna istraživanja su pokazala da je kulturalna adaptacija TZŠ, učinila ovaj test adekvatnijim za procenu intelektualnih sposobnosti dece iz edukativno depriviranih sredina (Biro, Novović i Tovilović, 2006; Jovanović, Smederevac i Tovilović, u štampi). Dakle, pokazano je da ovaj test zadovoljava jedan od najvažnijih kriterijuma kvalitetnog testa za procenu inteligencije dece, a to je uvažavanje kulturalnih specifičnosti testirane dece.

Cilj ovog rada je ispitivanje psihometrijskih karakteristika Testa zrelosti za školu. Radi prikazivanja psihometrijskih karakteristika ovog instrumenta utvrđene su:

a) mere pouzdanosti pojedinačnih subtestova TZŠ i testa u celini;

b) mere poređenja prediktivne moći subtestova TZŠ i TIP-1 u predikciji učiteljske procene kognitivnog funkcionisanja dece pri čemu su kontrolisani socioekonomski status i etnička pripadnost; 
c) mere povezanosti postignuća na subtestovima TZŠ i učiteljskih procena pojedinačnih kognitivnih sposobnosti dece;

d) mere povezanosti subtestova TIP-1 i TZŠ (konkurentna validnost).

\section{Metod}

Uzorak

Uzorak istraživanja je činilo 149 dece koja su pozivana na redovno testiranje za polazak u školu tokom aprila, maja i juna 2008. godine. Testiranje dece vršili su školski psiholozi u Šapcu i Sremskoj Mitrovici (grad i okolna sela). Prosečna starost ispitivane dece je bila 81 mesec $(\mathrm{SD}=3,30)$.

U cilju validacije nekih od pretpostavki na kojima je zasnovan $\mathrm{TZS}^{2}$, uzorak istraživanja je podeljen u tri grupe: grupu dece romskog porekla (52) i dve grupe dece neromskog porekla - iz porodica sa niskim socio-ekonomskim statusom (49) i iz porodica prosečnog socio-ekonomskog statusa (48). Pripadnost grupi sa niskim socio-ekonomskim statusom (SES) određivana je na osnovu unapred definisanih kriterijuma: (1) izloženost ekstremno neuslovnim životnim uslovima, (2) porodica prima socijalnu pomoć, (3) prihodi niži od 5000 dinara po članu domaćinstva (prisutnost bar dva od tri definisana kriterijuma).

Dve grupe porodica sa niskim socio-ekonomskim statusom (romska i neromska) su ujednačene po kriterijumu materijalne ugroženosti, a obe imaju značajno niži SES u odnosu na neromsku grupu prosečnog materijalnog stanja (ANOVA: $F(2,146)=28,24 ; \mathrm{p}<0,001$ ); (Scheffeov test za razliku između grupa sa niskim SES: $p>0,1$; između grupe sa prosečnim SES i dve grupe sa niskim SES: $\mathrm{p}<0,001)$.

\section{Instrumenti}

Test zrelosti za školu (TZŠ; Novović i sar., 2007) se sastoji od 5 subtestova. Informisanost predstavlja test praktičnog znanja i socijalne prilagođenosti (npr.

\footnotetext{
${ }^{2}$ TZŠ je konstruisan sa idejom da minimizira uticaj prethodnih nepovoljnih socioedukativnih faktora na postignuća ispitivane dece na testu
} 
Zašto treba prati ruke pre jela?). Vizuelna memorija je test namenjen proceni sposobnosti pamćenja i pažnje. Slaganje kocaka je test namenjen proceni sposobnosti vizuo-motorne koordinacije, perceptivne organizacije i planiranja. Šifra je test kojima se procenjuju sposobnosti vizuo-motorne koordinacije, učenja iz iskustva i koncentracije. Vizuelni rečnik predstavlja test lingvističke kompetencije i predstavlja alternativni test namenjen socijalno depriviranoj i deci čiji maternji jezik nije srpski.

Test za ispitivanje prvaka (TIP-1; Ivić, Milinković, Pešikan i Bukvić, 1995) je nastao 1989. na Institutu za psihologiju Filozofskog fakulteta u Beogradu. Ispituje inteligenciju dece uzrasta 6,8 do 7,4 godine i najčešće se koristi za ispitivanje spremnosti dece za polazak u školu. Sadrži raznovrsne zadatke koji su svrstani u pet grupa: Znanje, Pamćenje, Perceptivno zaključivanje, Verbalne sposobnosti i Logičke operacije. Ima zadovoljavajuću pouzdanost $(0,79)$ i konkurentnu validnost (korelacija sa WISC je 0,70), a pokazao se i validnim u predviđanju školskog uspeha (Vučić, Baucal i Petrović, 1994). Na našem uzorku dobijena je slična pouzdanost testa (Kronbah alfa $=0,78$ ).

Upitnik za učitelje je instrument konstruisan za potrebe ovog istraživanja. Zadatak učitelja je bio da nakon prvog polugodišta prvog razreda procene opšti uspeh ispitivane dece u savladavanju zahteva nastave i nivo razvijenosti: čitanja i pisanja, matematike, poznavanje jezika, fine motorike, pamćenja, i pažnje. Na svako pitanje učitelji su odgovarali zaokruživanjem broja na petostepenoj skali Likertovog tipa.

Prilikom ispitivanja prediktivne validnosti TZŠ u analizama su korišćene pojedinačne procene iz Upitnika za učitelje, kao i jedna globalna dimenzija učiteljske procene kognitivnog funkcionisanja deteta dobijena faktorizacijom pojedinačnih učiteljskih procena (prva glavna komponenta objašnjava 73,58\% varijanse).

\section{Rezultati}

\section{Pouzdanost TZŠ}

Kao što iz Tabele 1. vidimo, pouzdanost subtestova TZŠ je uglavnom zadovoljavajuća, kao i TZŠ u celini. Izuzetak je subtest Informisanost koji ima nisku internu konzistentnost $(\alpha=0,52)$ i nisku prosečnu inter-ajtem korelaciju $(0,11)$. 
Tabela 1. Pouzdanost subtestova i ukupnog skora TZŠ

\begin{tabular}{lcc}
\hline Subtestovi & Kronbah a & $\begin{array}{c}\text { Prosečne korelacije među } \\
\text { ajtemima }\end{array}$ \\
\hline Informisanost & .52 & .11 \\
Vizuelna memorija & .80 & .30 \\
Slaganje kocaka & .82 & .40 \\
Vizuelni rečnik & .77 & .26 \\
TZŠ ukupno (sa Vizuelnim rečnikom) & .87 & .17 \\
TZŠ ukupno (bez Vizuelnog rečnika) ${ }^{a}$ & .85 & .18 \\
\hline a Prikazani su pokazatelji pouzdanosti i za ukupni skor na TZŠ-u izračunat bez Vizuelnog reč- \\
nika, zato što on predstavlja opcioni subtest. Ukupni skor na TZŠ-u bez ovog subtesta kasnije u \\
radu je označen sa TZŠa.
\end{tabular}

Prediktivna validnost subtestova TZŠ u odnosu na TIP-1 u predviđanju globalne učiteljske procene kognitivnog funkcionisanja dece

Radi poređenja prediktivne validnosti TIP-1 i TZŠ podatke smo podvrgli hijerarhijskoj regresionoj analizi. Kriterijumsku varijablu su činili faktorski skorovi na prvoj glavnoj komponenti učiteljskih procena kognitivnog funkcionisanja dece. Prediktori su bili SES, etnička pripadnost i skorovi na subtestovima TZŠ i TIP-1. U prvom koraku su kao prediktori uključeni SES i etnička pripadnost deteta, kako bismo kontrolisali njihov uticaj na učiteljsku procenu kognitivnog funkcionisanja deteta. U drugom koraku su uključeni skorovi na subtestovima TIP-1, a u trećem koraku skorovi na subtestovima TZŠ. Cilj je bio da se ustanovi da li TZŠ, u odnosu na TIP-1 dodatno doprinosi predikciji učiteljskih procena. 
Tabela 2. Rezultati hijerarhijske regresione analize - subtestovi TIP-1 i TZŠ kao prediktori globalne učiteljske procene kognitivnog funkcionisanja dece

\begin{tabular}{|c|c|c|c|c|c|c|c|c|}
\hline $\begin{array}{l}\text { Mo- } \\
\text { del }\end{array}$ & Prediktori & $\mathrm{R}^{2}$ & $\Delta \mathrm{R}^{2}$ & $\beta^{a}$ & $\mathrm{t}$ & $\mathrm{p}$ & $r$ & $\mathrm{sr}^{2}$ \\
\hline \multirow[t]{3}{*}{1} & & .302 & .302 & & & \multirow{3}{*}{$\begin{array}{r}.060 \\
.000^{* * *} \\
* *\end{array}$} & & \\
\hline & SES ${ }^{b}$ & & & .177 & 1.892 & & .454 & .017 \\
\hline & Etnička pripadnost $\mathrm{t}^{\mathrm{b}}$ & & & .416 & 4.449 & & .534 & .096 \\
\hline \multirow[t]{8}{*}{2} & & .532 & .230 & & & & & \\
\hline & & & & -.014 & -.174 & .862 & .454 & .000 \\
\hline & Etnička pripadnost & & & .400 & 5.059 & . & .534 & .086 \\
\hline & TIP_Znanje & & & -.267 & -3.164 & $.002^{* *}$ & -.561 & -.025 \\
\hline & TIP_Pamćenje & & & -.109 & -1.537 & .127 & -.387 & -.007 \\
\hline & $\begin{array}{l}\text { TIP_Perceptivno } \\
\text { za-ključivanje }\end{array}$ & & & -.132 & -1.962 & .052 & -.392 & -.013 \\
\hline & $\begin{array}{l}\text { TIP_Verbalne } \\
\text { sposobnosti }\end{array}$ & & & -.047 & -.640 & .523 & -.340 & -.001 \\
\hline & $\begin{array}{l}\text { TIP_Logičke } \\
\text { operacije }\end{array}$ & & & -.122 & -1.428 & .155 & -.536 & -.007 \\
\hline \multirow[t]{13}{*}{3} & & .620 & .088 & & & & & \\
\hline & SES & & & .016 & .208 & .836 & .454 & .000 \\
\hline & Etnička pripadnost & & & .248 & 3.040 & $.003^{* *}$ & .534 & .026 \\
\hline & TIP_Znanje & & & -.189 & -2.346 & $.020^{*}$ & -.561 & -.016 \\
\hline & TIP_Pamćenje & & & -.040 & -.552 & .582 & -.387 & -.001 \\
\hline & $\begin{array}{l}\text { TIP_Perceptivno } \\
\text { zaključivanje }\end{array}$ & & & -.076 & -1.187 & .237 & -.392 & -.004 \\
\hline & $\begin{array}{l}\text { TIP_Verbalne } \\
\text { sposobnosti }\end{array}$ & & & -.002 & -.028 & .978 & -.340 & -.000 \\
\hline & $\begin{array}{l}\text { TIP_Logičke } \\
\text { operacije }\end{array}$ & & & -.061 & -.746 & .457 & -.536 & -.002 \\
\hline & TZŠ_Informisanost & & & -.272 & -3.650 & $.000^{* *}$ & -.591 & -.038 \\
\hline & $\begin{array}{l}\text { TZŠ_Vizuelna me- } \\
\text { morija }\end{array}$ & & & .063 & .855 & .394 & -.449 & .002 \\
\hline & $\begin{array}{l}\text { TZŠ_Slaganje } \\
\text { kocaka }\end{array}$ & & & -.251 & -3.372 & $.001^{* *}$ & -.573 & -.032 \\
\hline & TZŠ_Šifra & & & -.104 & -1.550 & .124 & -.492 & -.007 \\
\hline & TZŠ_Vizuelni rečnik & & & .098 & 1.370 & .173 & -.316 & .005 \\
\hline
\end{tabular}

Legenda. ${ }^{a}$ Negativni beta koeficijenti su posledica inverzije prve glavne komponente tako da viši skorovi kriterijumske varijable označavaju niže učiteljske procene; ${ }^{\text {b } K o d ~ v a r i j a b l e ~} S E S$ ispitanicima prosečnog socio-ekonomskog statusa pripisan je broj 1, a ispitanicima niskog socioekonomskog statusa broj 2. Kod varijable etnička pripadnost neromska deca su označena brojem 1 , a romska brojem 2 ; ${ }^{*} \mathrm{p}<0,05$; ** $\mathrm{p}<0,01$.

Rezultati pokazuju da SES i etnička pripadnost, uključeni u prvom koraku hijerarhijske regresione analize, objašnjavaju 30,2\% varijanse globalne učiteljske 
procene kognitivnog funkcionisanja dece $(F(2,144)=31,172 ; \mathrm{p}<0,001)$. Kao značajan prediktor se izdvaja etnička pripadnost, dok je Beta koeficijent za SES marginalno značajan (tabela 2). Subtestovi TIP-1, uključeni u drugom koraku, objašnjavaju dodatnih $23 \%$ varijanse kriterijuma (značajnost promene: $F(5,139)=13,65 ; p<0,001)$, pri čemu je najbolji prediktor subtest Znanje. Ovaj rezultat pokazuje da TIP-1 značajno doprinosi predikciji kriterijuma i nakon kontrole SES i etničke pripadnosti.

Subtestovi TZŠ uključeni u trećem koraku, obašnjavaju dodatnih $8,8 \%$ varijanse kriterijuma $(F(5,134)=6,23 ; \mathrm{p}<0,001)^{3}$. Kao najznačajniji prediktori globalne učiteljske procene kognitivnih sposobnosti deteta pokazali su se Informacije i Slaganje kocaka. Uvid u semiparcijalne korelacije pokazuje da ova dva subtesta TZŠ imaju i najveći jedinstveni doprinos u objašnjavanju varijanse učiteljske procene. Rezultati hijerarhijske regresione analize su demonstrirali da TZŠ ima odličnu prediktivnu validnost. Naime, pokazalo se da postignuće na subtestovima TZŠ ostvaruje najveće efekte na globalnu učiteljsku procenu detetovih kognitivnih sposobnosti, nakon kontrole uticaja SES-a i etničke pripadnosti i parcijalizacije deljene varijanse sa subtestovima TIP-1.

\section{Prediktivna validnost subtestova TZŠ u odnosu na pojedinačne učiteljske pro- cene kognitivnog funkcionisanja dece}

Rezultati prikazani u tabeli 3. ukazuju na dobru prediktivnu validnost subtestova TZŠ. Naime, subtestovi TZŠ ostvaruju značajne korelacije sa gotovo svim pojedinačnim učiteljskim procenama (postoji samo jedan izuzetak u slučaju subtesta Vizuelni rečnik). Korelacije se kreću do 0,63 i pretežno su umerenog intenziteta. Najviše korelacije subtestovi ostvaruju sa učiteljskom procenom savladanosti gradiva iz matematike, čitanja i pisanja, kao i procenom detetove sposobnosti pamćenja. Subtestovi koji najviše koreliraju sa učiteljskim procenama su Informisanost i Slaganje kocaka.

Subtestovi TZŠ koreliraju sa pojedinačnim učiteljskim procenama u skladu sa očekivanjima tj. značajno su povezani sa specifičnim domenima/funkcijama koje pretenduju da mere. Informisanost korelira sa čitanjem i pisanjem $(0,56)$ i pamćenjem $(0,63)$, Vizuelna memorija korelira sa procenom sposobnosti pamćenja $(0,40)$, Slaganje kocaka sa stepenom savladanosti matematike $(0,56)$,

\footnotetext{
${ }^{3}$ Multipla regresiona analiza subtestova TZŠ u predikciji globalne učiteljske procene kognitivnog funkcionisanja pokazuje da postignuće na subtestovima objašnjava $52,9 \%$ varijanse $(\mathrm{F}=31,668, \mathrm{p}<0,001)$.
} 
kao i nivoom razvijenosti fine motorike $(0,43)$, Šifra sa razvijenošću pažnje i koncentracije $(0,41)$, Vizuelni rečnik sa pamćenjem $(0,31)$.

Tabela 3. Linearne korelacije izmedu postignuća na subtestovima TZŠ i pojedinačnih učiteljskih procena kognitivnog funkcionisanja dece

\begin{tabular}{|c|c|c|c|c|c|c|c|}
\hline \multicolumn{8}{|l|}{$\begin{array}{l}\text { Subtestovi } \\
\text { TZŠ }\end{array}$} \\
\hline $\begin{array}{l}\text { Učiteljske } \\
\text { procene }\end{array}$ & $\begin{array}{c}\text { Infor- } \\
\text { mi- } \\
\text { sanost }\end{array}$ & $\begin{array}{l}\text { Vizuel- } \\
\text { na } \\
\text { memo- } \\
\text { rija }\end{array}$ & $\begin{array}{c}\text { Slaga } \\
\text { nje } \\
\text { ko- } \\
\text { caka }\end{array}$ & Šifra & $\begin{array}{l}\text { Vizu- } \\
\text { elni } \\
\text { rečnik }\end{array}$ & $\begin{array}{l}\text { TZŠ } \\
\text { suma }\end{array}$ & TZŠa \\
\hline $\begin{array}{l}\text { Čitanje i } \\
\text { pisanje }\end{array}$ & $.56^{* *}$ & $.44^{* *}$ & $.51^{* * *}$ & $.47^{* *}$ & $.28^{* *}$ & $.63^{* *}$ & $.63^{* *}$ \\
\hline Matematika & $.58^{* *}$ & $.46^{* *}$ & $.56^{* *}$ & $.46^{* *}$ & $.31^{* *}$ & $.66^{* *}$ & $.65^{* *}$ \\
\hline $\begin{array}{l}\text { Vladanje } \\
\text { jezikom }\end{array}$ & $.42^{* *}$ & $.23^{* *}$ & $.32^{* *}$ & $.24^{* *}$ & $.25^{* *}$ & $.38^{* *}$ & $.37^{* *}$ \\
\hline $\begin{array}{l}\text { Fina } \\
\text { motorika }\end{array}$ & $.30^{* *}$ & $.30 * *$ & $.43^{* *}$ & $.39^{* *}$ & .16 & $.47^{* *}$ & $.49^{* *}$ \\
\hline Pamćenje & $.63^{* *}$ & $.40^{* *}$ & $.53^{* *}$ & $.42^{* *}$ & $.31^{* *}$ & $.62^{* *}$ & $.62^{* *}$ \\
\hline Pažnja & $.49^{* *}$ & $.27^{* *}$ & $.44^{* *}$ & $.41^{* *}$ & $.29 * *$ & $.52^{* *}$ & $.51^{* *}$ \\
\hline
\end{tabular}

Rezultati pokazuju da Vizuelni rečnik generalno ima najniže korelacije sa pojedinačnim učiteljskim procenama. Ukupan skor na TZŠ-u ima umerene do visoke korelacije sa svim sposobnostima koje su učitelji procenjivali - najvišu sa procenom matematičkih sposobnosti, a najnižu sa procenom razvijenosti lingvističke kompetentnosti.

\section{Konkurentna validnost subtestova TZŠ}

Konkurentna validnost TZŠ je ispitivana na osnovu povezanosti sa subtestovima TIP-1. Rezultati prikazani u tabeli 4. pokazuju da ukupni skorovi na TZŠ i TIP-1 visoko koreliraju $(r=0,66)$. Ustanovljena je i značajna povezanost između pojedinačnih subtestova ova dva instrumenta, pri čemu najviše korelacije ostvaruju subtestovi koji pretenduju da mere slične konstrukte. 
Tabela 4. Linearne korelacije izmedu subtestova TZŠ $i$ TIP-1

TZŠ

\begin{tabular}{lccccccc}
\hline TIP-1 & $\begin{array}{c}\text { Infor- } \\
\text { mi- } \\
\text { sanost }\end{array}$ & $\begin{array}{c}\text { Vizuelna } \\
\text { memo- } \\
\text { rija }\end{array}$ & $\begin{array}{c}\text { Slaga- } \\
\text { nje } \\
\text { kocaka }\end{array}$ & Šifra & $\begin{array}{c}\text { Vizuel- } \\
\text { ni } \\
\text { rečnik }\end{array}$ & $\begin{array}{c}\text { TZŠ } \\
\text { ukup- } \\
\text { no }\end{array}$ & TZŠa \\
\hline $\begin{array}{l}\text { Znanje } \\
\text { Pamćenje }\end{array}$ & $.60^{* *}$ & $.36^{* *}$ & $.37^{* *}$ & $.36^{* *}$ & $.38^{* *}$ & $.52^{* *}$ & $.50^{* *}$ \\
$\begin{array}{l}\text { Perceptivno } \\
\text { zaključivanje }\end{array}$ & $.30^{* *}$ & $.23^{* *}$ & $.29^{* *}$ & $.36^{* *}$ & .06 & $.40^{* *}$ & $.43^{* *}$ \\
$\begin{array}{l}\text { Verbalne spo- } \\
\text { sobnosti }\end{array}$ & $.45^{* *}$ & $.29^{* *}$ & $.26^{* *}$ & $.26^{* *}$ & $.42^{* *}$ & $.42^{* *}$ \\
$\begin{array}{l}\text { Logičke ope- } \\
\text { racije }\end{array}$ & $.50^{* *}$ & $.44^{* *}$ & $.50^{* *}$ & $.42^{* *}$ & $.47^{* *}$ & $.42^{* *}$ & $.39^{* *}$ \\
$\begin{array}{l}\text { TIP-1 ukupno } \\
.62^{* *}\end{array}$ & $.43^{* *}$ & $.50^{* *}$ & $.49^{* *}$ & $.49^{* *}$ & $.66^{* *}$ & $.59^{* *}$ \\
\hline *** $\mathrm{p}<01$ & & & & & & & $.64^{* *}$ \\
\hline
\end{tabular}

Informisanost iz TZŠ najviše korelira sa Znanjem iz TIP-1 (0,60), Slaganje kocaka sa Logičkim operacijama $(0,50)$, a Vizuelni rečnik sa Verbalnim sposobnostima (0,37). Iznenađujući rezultat je da Vizuelna memorija iz TZŠ najviše korelira sa Logičkim operacijama iz TIP-1, i pokazuje nižu povezanost sa subtestovima Pamćenje i Perceptivno zaključivanje. Pored toga, Šifra iz TZŠ najviše korelira sa Logičkim operacijama, a ne sa Pamćenjem i Perceptivnim zaključivanjem iz TIP-1 što bismo očekivali na osnovu prirode materijala i kognitivnih operacija koje Šifra kao subtest zahteva. Sa ukupnim rezultatom na TIP-1 najviše korelira Informisanost, a najmanje Vizuelna memorija.

\section{Diskusija}

TZŠ je pokazao zadovoljavajuću relijabilnost (internu konzistentnost) kao test u celini, a i većina subskala se pokazuje pouzdanima. Rezultati su utoliko uverljiviji što subtestovi imaju mali broj ajtema. Jedino se subtest Informisanost pokazao nedovoljno pouzdanim u smislu niske interne konzistentnosti. Razlog niske pouzdanosti ovog subtesta je najverovatnije raznorodnost zadataka koje on sadrži. Naime, ideja autora TZŠ je bila da njime meri više različitih sposobnosti. Neke od njih se pretežno oslanjaju na bogatstvo i dostupnost 
informacija u dugotrajnoj memoriji, dok se pojedinim zadacima ovog subtesta mere sposobnost logičkog rezonovanja i usvojenost socijalnih normi (slično zadacima subtesta Shvatanje iz Vekslerovih skala - npr. Zašto ljudi moraju da rade?). Iako subtest Informisanost ispoljava nisku internu konzistentnost, njegove ostale psihometrijske karakteristike su odlične - on ima najveću prediktivnu i konkurentnu validnost. Ovo sugeriše ne samo korisnost ovog subtesta kao pokazatelja bogatstva stečenih informacija, već i kao najboljeg prediktora detetovih postignuća na osnovu procene učitelja.

Prediktivna validnost TZŠ je proveravana pomoću hijerarhijske regresione analize, gde je kriterijum bila globalna učiteljska procena kognitivnog funkcionisanja ispitivane dece. Uključivanjem i subtestova TIP-1 u analizu, ispitali smo kakva je prediktivna moć ova dva instrumenta za procenu spremnosti dece za školu, nakon što se parcijalizuje njihova deljena varijansa. Unošenje SES i romske nasuprot neromske nacionalnosti $u$ analizu imalo je za cilj da ustanovi i kontroliše uticaj ovih varijabli na učiteljske procene.

SES se u prvom koraku analize pojavio kao marginalno značajan prediktor učiteljske procene kognitivnog funkcionisanja dece. Nakon uvođenja subtestova TIP-1 (u drugom koraku) i TZŠ (u trećem koraku) kao prediktora, njegov značaj se izgubio. Ovaj nalaz ukazuje da na učiteljsku procenu kognitivnog funkcionisanja dece objektivni (testovni) pokazatelji dečijih sposobnosti imaju veći efekat od socioekonomskog statusa deteta.

Zanimljiv podatak je da prilikom predikcije učiteljske procene etnička pripadnost deteta ima značajno veći uticaj od socio-ekonomskog statusa deteta. Rezultati pokazuju da etnička pripadnost ima značajan uticaj na učiteljske procene kognitivnog funkcionisanja dece, čak i nakon parcijalizacije deljene varijanse sa skorovima na TIP-1 i TZŠ. Moguće objašnjenje je da je uticaj etničke pripadnosti pokazatelj stereotipnog gledanja na romsku decu kao slabije đake. Naime, u nekim novijim istraživanjima u našoj sredini je uočeno da učitelji imaju veoma niska očekivanja od romskih učenika (Baucal, 2006).

Rezultati hijerarhijske regresione analize su pokazali da TZŠ ima odličnu prediktivnu validnost. Naime, postignuće na subtestovima TZŠ ostvaruje najveći uticaj na globalnu učiteljsku procenu detetovih kognitivnih sposobnosti, nakon kontrolisanja efekata socioekonomskog statusa i etničke pripadnosti i parcijalizacije deljene varijanse sa subtestovima TIP-1. Iako i TIP-1 ispoljava dobru prediktivnu validnost, pogotovo kad su u pitanju subtestovi Znanje i Perceptivno zaključivanje, postignuće na TZŠ-u ostvaruje značajan dodatni doprinos u predikciji kriterijuma. Pri tom, subtestovi Informacije i Slaganje kocaka iz TZŠ imaju najveći jedinstveni doprinos. Subtest Perceptivno zaklju- 
čivanje iz TIP-1, nakon uključivanja subtestova TZŠ u analizu, nije više značajan prediktor. Ovaj rezultat sugeriše da subtestovi TZŠ, pogotovo Informisanost i Slaganje kocaka, obuhvataju ne samo slične sposobnosti koje meri Perceptivno zaključivanje iz TIP-1, već i nešto više od njih.

Od pojedinačnih subtestova TZŠ, Informisanost ima najviše korelacije sa učiteljskim procenama kognitivnog funkcionisanja prvaka. On visoko korelira sa učiteljskom procenom pamćenja, matematičkih sposobnosti, čitanja i pisanja, a značajno korelira i sa ostalim procenjivanim sposobnostima/postignućima deteta. Veze Informisanosti sa pamćenjem i čitanjem/pisanjem su očekivane i razumljive, obzirom da se bogatstvo informacija jasno oslanja na dugoročno pamćenje. Ali, (manje očekivana) veza Informisanosti sa procenom savladanosti gradiva iz matematike pre bi se mogla objasniti pominjanom heterogenošću zadataka subtesta Informisanost. Neki od tih zadataka zahtevaju i logičko rezonovanje koje je neophodno i za matematičke sposobnosti. Osim toga, moguće je da se ova povezanost ostvaruje i preko dugotrajne memorije koja predstavlja osnovu za mnoge druge sposobnosti, pa tako i matematičke ili preko zasićenosti generalnim faktorom inteligencije (Plante, 2005).

Subtest Slaganje kocaka predstavlja drugi značajan prediktor pojedinačnih učiteljskih procena. Od svih subtestova TZŠ, Slaganje kocaka najviše korelira sa razvijenošću motorike. Time se potvrđuje uloga ovog subtesta u proceni vizuomotornih sposobnosti, koju su i pretpostavili autori. Od svih procenjivanih sposobnosti, sa Slaganjem kocaka najvišu korelaciju ostvaruje učiteljska procena matematičkih sposobnosti. Veza je verovatno posredovana nizom specifičnih sposobnosti (poput apstraktnog mišljenja ili logičkog rezonovanja), preko opštijih karakteristika kognitivnog funkcionisanja kao što je koncentracija, pa do najopštijih kao što je globalna inteligencija (Groth-Marnat, 1999). Ako se ovim rezultatima pridoda značajan jedinstveni doprinos koji Slaganje kocaka imaju u odnosu na opšti kriterijum učiteljske procene uspešnosti u školskim veštinama, dolazi se do zaključka da je ovaj subtest TZŠ jedan od najkorisnijih pokazatelja intelektualnog funkcionisanja deteta uopšte, kao i onog koje je neophodno za savladavanje školskog gradiva.

Šifri se po našim rezultatima može pripisati treće mesto po merama validnosti. Čak četiri korelacije Šifre sa pojedinačnim postignućima/sposobnostima deteta prema oceni učitelja prelaze 0,40 . Ovaj subtest ostvaruje i značajne, no nešto niže korelacije sa subtestovima TIP-1 (prvenstveno sa subtestom Logičke operacije). Prema ideji autora testa, Šifra iz TZŠ bi trebalo da meri iste kognitivne funkcije kao istoimeni Vekslerov subtest, a način rešavanja je pojednostavljen kako bi se manje oslanjao na grafomotoriku koja je zavisna od edu- 
kativne sredine deteta. No, motorika je, sudeći po rezultatima, ipak uključena u rešavanje ovog zadatka.

Najviše korelacije Šifra ostvaruje sa čitanjem-pisanjem, matematikom, pamćenjem i pažnjom. Šifra je i u Vekslerovim testovima subskala koja je u vezi sa sposobnošću praćenja direkcije, kratkotrajnom memorijom i mentalnom fleksibilnošću, drugim rečima različitim aspektima pažnje (Groth-Marnat, 1999). Uz podsećanje da je ovo jedan od subtestova sa vremenskim ograničenjem, možemo zaključiti da je Šifra dobar pokazatelj nekih specifičnih i nekih opštijih kognitivnih sposobnosti neophodnih za usvajanje školskih veština i gradiva. Ujedno, ovaj subtest je i generalni pokazatelj trenutne efikasnosti - sposobnosti korišćenja potencijala i odolevanja ometajućim (spoljašnjim i unutrašnjim) uticajima.

Slično Šifri, Vizuelna memorija ostvaruje najviše korelacije sa matematikom i čitanjem-pisanjem. Povezanost sa pamćenjem je takođe umerenog intenziteta, ali nešto niža od prethodne dve. Veza Vizuelne memorije sa učiteljskim procenama usvojenosti čitanja/pisanja i matematike bi mogla biti posredovana sposobnošću konceptualizacije, tj. formiranja pojma. Ta sposobnost predstavlja osnovu za usvajanje pisma i brojeva, kao i za osmišljavanje slika iz zadataka Vizuelne memorije. Najviše korelacije Vizuelne memorije TZŠ sa Logičkim operacijama i Znanjem iz TIP-1, idu u prilog ovom objašnjenju.

U odnosu na ostale subtestove TZŠ najslabiju prediktivnu validnost pokazao je Vizuelni rečnik. Njegove korelacije sa učiteljskim procenama pojedinačnih kognitivnih sposobnosti/funkcija su značajne (izuzetak čini povezanost sa motorikom), ali su mahom niskog intenziteta. No, neophodno je naglasiti da je Vizuelni rečnik opcioni test TZŠ koji se zadaje u slučaju upitne jezičke kompetentnosti deteta, tj. kada ispitivač proceni da je detetova usvojenost jezika na kojem će se izvoditi nastava problematična. U osnovi, o prediktivnoj validnosti ovog subtesta ne možemo ni izneti pouzdan zaključak, s obzirom da uzorak istraživanja ni ne pogoduje njegovoj validaciji (malobrojnost dece sa slabim poznavanjem srpskog jezika i visoka prosečna ocena savladanosti jezika nastave od strane učitelja).

\section{Zaključci}

Na osnovu nalaza istraživanja, mogu se izvesti sledeći zaključci:

- TZŠ u celini, kao i većina njegovih subtestova imaju zadovoljavajuću relijabilnost. 
- $\quad$ TZŠ ima zadovoljavajuću prediktivnu i konkurentnu validnost, kako u celini tako i na nivou pojedinačnih subtestova.

- Subtestovi TIP-1 značajno predviđaju učiteljske procene usvojenosti školskih veština i kognitivnog funkcionisanja nakon prvog polugodišta prvog razreda. Kao najbolji prediktori pokazuju se subtestovi Znanje i Perceptivno zaključivanje.

- Subtestovi TZŠ imaju značajno veću prediktivnu validnost od TIP-1, tj. ostvaruju značajan dodatni doprinos u predikciji učiteljskih procena kada se kontroliše uticaj etničke pripadnosti i socio-ekonomskog statusa porodice iz koje potiču ispitivana deca. Subtestovi Informisanost i Slaganje kocaka ostaju značajni prediktori učiteljskih procena kognitivnih sposobnosti/postignuća dece i nakon parcijalizacije deljene varijanse sa subtestovima TIP-1.

- Najveću prediktivnu i konkurentnu validnost pokazuju subtestovi TZŠ: Informisanost, Slaganje kocaka i Šifra. Vizuelna memorija takođe pokazuje zadovoljavajuće psihometrijske karakteristike. O zadovoljavajućoj prediktivnoj vrednosti subtesta Vizuelni rečnik možemo samo uslovno govoriti, s obzirom da istraživački uzorak nije pogodavao njegovoj adekvatnoj validaciji.

\section{Literatura}

Bagnato, S. J., \& Neisworth, J. T. (1994). A national study of the social and treatment „invalidity“ of intelligence testing for early intervention. School Psychology Quarterly, 9, 81-102.

Baucal, A. (2006). Development of mathematical and language literacy among Roma students. Psihologija, 39, 207-227.

Berger, J., Marković, M. i Mitić, M. (1995). Priručnik za Vekslerov Individualni Test Inteligencije. Beograd: Društvo psihologa Srbije.

Biro, M., Novović, Z. i Tovilović, S. (2006). Kognitivno funkcionisanje edukativno zapuštene dece predškolskog uzrasta. Psihologija, 39, 183-204.

Flanagan, D. P., \& Alfonso, V. C. (1995). A critical review of the technical characteristics of new and resently revised intelligence tests for preschool children. Journal of Psychoeducational Assessment, 13, 66-90. 
Garber, H. L., \& Slater, M. (1983). Assessment of culturally differrent preschooler. In K. D. Paget \& B. A. Bracken (Eds.) The psychoeducational assessment of preschool children (str. 443-471). New York: Grune i Stratton.

Groth-Marnat, G. (1999). Handbook of psychological assessment. New York: John Wiley and Sons.

Hale, J. B., Fiorello, C. A., Kavanagh, J. A., Holdnack, J. A., \& Aloe, A. M. (2007). Is the demise of IQ interpretation justified? A response to special issue authors. Applied Neuropsychology, 14, 37-51.

Ivić, I., Milinković, M., Pešikan, A. i Bukvić, A. (1995). Test za ispitivanje prvaka (TIP-1) - Priručnik. Beograd: Društvo psihologa Srbije.

Ivić, I. D., Milinković, M., Rosandić, R. i Smiljanić-Čolanović, V. (1976). Priručnik za NBS. Beograd: Zavod za udžbenike i nastavna sredstva.

Jensen, A. R. (1998). The g factor: The science of mental ability. Westport, CT: Praeger.

Jovanović, V., Smederevac, S. i Tovilović, S. (u štampi). Sredinski činioci neuspeha romske dece na Testu zrelosti za školu. Zbornik Instituta za pedagoška istraživanja.

Kaufman, A. S., \& Kaufman, N. L. (2001). Specific learning disabilities and difficultes in children and adolescents: Psychological assessment and evaluation. Cambridge: Cambridge University Press.

Neisser, U., Boodoo, G., Bouchard, T. J., Boykin, A. W., Brody, N, Ceci, S. J., Halpern, D. F., Loehlin, J. C., Perloff, R., Sternberg, R. J., \& Urbina, S. (1996). Intelligence: knowns and unknowns. American psychologist, 51, 77-101.

Nijenhuis, J., Tolboom, E., Resing, W., \& Bleichrodt, N. (2004). Does cultural background influence the intellectual performance of children from immigrant groups? European Journal of Psychological Assessment, 20, 1026.

Novović, Z., Biro, M., Baucal, A., i Tovilović, S. (2007). Test zrelosti za školu. Beograd: Društvo psihologa Srbije.

Plante, T.G. (2005). Contemporary clinical psychology. New Jersey: John Wiley and Sons. 
Sattler, J. M. (1992). Assessment of children (3rd ed.). San Diego, CA: Author. Simić, Lj., i Mihajlović, M. (1998). Opravdanost upotrebe testa TIP-1 van standardizacionog područja. Nastava $i$ vaspitanje, 47, 265-274.

Sternberg, R. J., Grigorenko, E. L., \& Bundy, D. A. (2001). The predictive value of IQ. Merill-Palmer Quarterly, 47, 1-41.

Tovilović, S. i Baucal, A. (2007). Procena zrelosti za školu - Kako pristupiti problemima procene i adaptacije marginalizovane dece na školu? Beograd: Centar za primenjenu psihologiju.

Ulrey, G. (1981). The challenge of providing psychological services for young handicapped children. Professional Psychology, 12, 483-491.

Vučić, L., Baucal, A., i Petrović, D. (1994). Faktori uspešnosti na testovima intelektualnih sposobnosti pri polasku u školu. Nastava $i$ vaspitanje, 18, 433455. 


\section{ABSTRACT}

\section{VALIDATION OF THE SCHOOL MATURITY TEST}

Zdenka Novović, Snežana Tovilović, Veljko Jovanović \& Mikloš Biro

The purpose of this study is to examine psychometric properties of the School Maturity Test (SMT). The sample consisted of 149 children with average age of 81 months. The data were collected during regular testing of a school maturity in elementary schools in Šabac and Sremska Mitrovica. The results provided support for high reliability of SMT. Correlation between SMT and TIP1 (earlier test with same appropriation) global scores was 0.66 , and high correlations were also obtained among subtests which were expected to measure similar constructs. Therefore, it was concluded that SMT displayed high concurrent validity. Furthermore, the predictive validity of SMT was examined in relation to teachers' evaluation of cognitive functioning, conducted among first graders after their first term. The results showed excellent predictive validity of SMT subtests, among which Informations and Block design subtests reached the highest predictive power.

Key words: school maturity, intelligence tests, School Maturity Test 